\title{
Agricultural technology adoption, commercialization and smallholder rice farmers' welfare in rural Nigeria
}

\author{
Bola Amoke Awotide ${ }^{1 *}$, Aziz A. Karimov ${ }^{2}$ and Aliou Diagne ${ }^{3}$
}

\author{
* Correspondence: \\ bawotide@yahoo.com \\ ${ }^{1}$ Agricultural Economics, University \\ of Ibadan, Ibadan, Ibadan 200001 \\ Nigeria \\ Full list of author information is \\ available at the end of the article
}

\begin{abstract}
This study assessed the determinants of intensity of adoption of Improved Rice Varieties (IRVs) and the effect of market participation on farmers' welfare in Nigeria using the Tobit and Heckman two-stage models, respectively. The sample consists of crosssectional data of 600 rice farmers selected randomly from three notable rice producing States in Nigeria. The variables that positively and significantly influenced the intensity of IRVs adoption include income from rice production, membership of a farmers' organization, and the distance to the nearest sources of seed, cost of seed, yield and level of training. Gender of household head, access to improved seed, years of formal education, and average rice yield were those variables that are positive and statistically significant in increasing the probability that a farmer would participate in the market. The result further suggests that any increase in the farmers' welfare is conditional on the probability of the farmer participating in the rice output markets. In addition, higher yield, income from rice production, gender of household head, and years of formal education are the variables that are positive and statistically significant in determining households' welfare. Therefore, it is recommended that formation of associations among the rural farmers should be encouraged. Access to seed and information about the IRVs are also essential to increase the intensity of its adoption. Programmes to improve contact with extension agents, increased access to credit, raising educational background and increasing the area devoted to cultivating IRVs are the factors to be promoted in order to increase market participation and hence improve the welfare of rural households.
\end{abstract}

Keywords: Rice, Adoption, Commercialization, Farming, Welfare, Nigeria

JEL classification: Q13, Q16, O13

\section{Background}

The agricultural sector continues to play a dominant and strategic role in the development and growth of most developing nations of the world. Most importantly, its role as a source of employment cannot be overemphasised. In Sub-Saharan Africa (SSA), Asia and the Pacific, the agriculture-dependent population is over $60 \%$, while in Latin America and high income economies the proportions are estimated to be around $18 \%$ and $4 \%$, respectively (World Bank, 2006). Therefore, the agricultural sector is vital for bringing about economic growth and development, overcoming poverty and enhancing food security. However, the aforementioned potentials of the agricultural sector could

\section{Springer}

(c) 2016 Awotide et al. Open Access This article is distributed under the terms of the Creative Commons Attribution 4.0 International License (http://creativecommons.org/licenses/by/4.0/), which permits unrestricted use, distribution, and reproduction in any medium, provided you give appropriate credit to the original author(s) and the source, provide a link to the Creative Commons license, and indicate if changes were made. 
only be achieved through an increase in productivity of smallholder farmers as emphasised in the 2008 World Development Report. Thus, boosting agricultural productivity has been an issue of paramount importance to development institutions across the globe and in order to achieve this, the use of technological improvements have played a key role (Maertens and Barrett, 2013). Agricultural innovations also play a significant role in fighting poverty, lowering per unit costs of production (Kassie et al. 2011), boosting rural incomes and reducing hunger (Maertens and Barrett, 2013).

Based on the success stories that emanated from the Green Revolution in Asia, efforts to increase agricultural productivity in Africa have been directed towards the adoption of improved agricultural innovations. It is believed that improved agricultural technology adoption, such as using improved seed varieties, could inspire the changeover from the presently low productivity, peasant, and subsistence farming to commercial farming (which is able to produce surpluses). Improved agricultural technology adoption has the potential to deepen the market share of agricultural output through which the smallholder farmers' resource use and output diversification decisions could be guided increasingly by their objective of profit maximization. Thus, leading to an emphasis on the importance of purchased inputs and a reduction in the use of non-traded inputs - boosting the growth of specialized commercial farming units (Omiti et al. 2009) in developing countries. This emphasis in turn will boost competition in the market, lower marketing and processing costs and lead to a decrease in real food price (Jayne et al. 2005).

In Nigeria for instance, due to the fact that rice is the most important staple food crop, the government prioritized the development and dissemination of IRVs (e.g. NERICA 1, 2 and 8, Faro 52, 54 etc.) and provision of adequate seed in a timely manner and at affordable prices to rice farmers (Awotide et al. 2013). These improved varieties offer new opportunities for farmers because of their unique characteristics, such as shorter period of growth, higher yield and greater tolerance to major stresses, increased protein contents and tasting better than the traditional cultivars/varieties. The adoption of these improved varieties is very vital, in view of the fact that it is becoming more obvious that traditional subsistence smallholding farming systems can no longer meet the needs and expectation of an everincreasing population of Nigeria.

Evidence abounds in the literature on the positive impact of IRVs adoption on productivity, poverty reduction and welfare (Mendola, 2007; Diagne et al., 2009; Dontsop-Nguezet et al. 2011; Awotide et al. 2012), however, it is also recorded that in Nigeria despite the adoption of improved varieties and the consequent positive impact on productivity, poverty among farmers is still highly endemic and the rural areas are still characterised by deplorable living conditions. The World Bank (2007) posited that one important route to reduce poverty in rural areas is to enhance the market participation of smallholder rural farmers, as this can increase the net returns to agricultural production. For smallholder agriculture to achieve sustainable increase in productivity and improvement in farm profit, intensification and commercialisation are fundamental.

However, evidence suggests that currently smallholder farmers do not often participate in staple food markets and their overall market share is still very low (Jayne et al. 2005). For instance, Jayne et al. (2005) found that top $2 \%$ of 
commercial farmers sold about $50 \%$ of the maize marketed in Kenya, Mozambique and Zambia. Ellis (2005) also showed that farmers in semi-arid areas of Africa are able to market only a very low proportion of their output. Therefore, these facts raise some vital questions that this study intends to answer. For instance, what are the factors that influence the intensity of IRVs adoption? What are those socio-economic/demographic characteristics of farmers that determine their participation in output markets and, what is the likely subsequent effect of market participation on rice farmers' welfare in Nigeria?

Many studies have been conducted to assess the determinants and intensity of agricultural technology adoption (Adesina and Seidi, 1995; Adesina, 1996; Awotide et al. 2012) and its impact on welfare and poverty reduction (Diagne and Demont, 2007; Diagne et al. 2009; Wu et al. 2010; Awotide et al. 2011; Dontsop-Nguezet et al. 2011; Amare et al. 2012). These studies underline the positive impact of adoption of improved (seed) varieties on household livelihoods. However, studies that have analysed the relationship between improved agricultural technology adoption, market participation and overall welfare among the rural farming households is still very scarce in the literature. This study intends to identify the physical and socioeconomic factors that affect the intensity of adoption of IRVs, to examine the determinants of market participation and then to analyse the subsequent effect of market participation on rice farmers' welfare in Nigeria. Through the results that emanated from this study, the policy makers would be informed on why there has been an increase in rice yield without a proportionate improvement in the welfare of rural farming households. In addition, it will also shed light on the socio-economic variables that influence market participation, which can help in the development of policies that would assist farmers to shift from subsistence farming to commercial production.

The remaining part of the paper is organized as follows: section two presents research methods used in this study, section three and four are concerned with results and discussion and the last section is devoted to conclusions and policy recommendations.

\section{Research methods}

\section{Data collection}

This study used primary data collected by the Africa Rice Centre (AfricaRice) under the Emergency Rice Initiative programme financially supported by the United State Agency for International Development (USAID). The data was collected in 2010 through multistage random sampling. In the first stage three major rice growing systems (lowland, upland and irrigated) were purposively selected, and Kano, Osun and Niger States were randomly chosen to represent each of the selected rice growing systems of interest in the second stage. In the third stage, two rural Agricultural Development Programmes (ADP) zones were purposively chosen from each of the three selected States. Five Local Government Areas (LGAs) from the two selected ADP zones were randomly selected in the fourth stage. The fifth stage involved random selection of three villages from Niger state and two each from Kano and Osun states. In the final stage, rice growing households were randomly selected from the chosen villages. Hence, 20 rice farming households were selected from each of the selected villages in Niger state and 15 each from other two States. Overall, 600 rice farmers participated in the survey. 


\section{Analytical framework and estimation techniques}

\section{Intensity of adoption of improved rice varieties: the tobit model}

Rogers and Shoemaker (1971) defined adoption as the decision to apply an innovation and to continue using it. This study employs the utility maximization theory, to describe responsiveness of farmers to new technology adoption (Adesina and Seidi, 1995; Adesina, 1996). A farmer switches from traditional to IRVs only if utility achieved from the latter is higher than from the former. If $U_{i 0}$ is the utility derived from the use of the traditional rice variety, while $U_{i 1}$ is the expected utility from the adoption of new IRVs, then, although not observed directly, the utility that a farmer $i$ derived from adopting a given measure of the IRVs $(j)$ can be expressed as:

$$
U_{i j}=X_{i} \beta_{j}+\tau_{i j} j=1,0 ; i=1, \ldots \ldots, n
$$

Where $X_{i}$ is a farm-specific function, $\beta_{j}$ is a parameter to be estimated, $\tau_{i j}$ is a disturbance term with mean zero and constant variance.

The adoption variable is a dummy, with 1 indicating adoption and 0 otherwise. A farmer adopts any of the new IRVs $(j=1)$, if $U_{i 1}>U_{i 0}$. Many of the studies that have assessed the adoption of improved agricultural technologies utilized either probit, logit or Tobit model. Following Dereje (2006) and Taha (2007), among many other studies, we utilised the Tobit model to analyse the intensity of adoption; measured by the average proportion of farmland devoted by the farmers to the production of IRVs. The Tobit model is a hybrid of the discrete and the continuous dependent variable proposed by Tobin (1958) and shows the link between a non-negative exogenous variable $y_{i}$ and an independent variable (or vector) $X_{i}$. The Tobit model assumes a latent unobservable $y_{i}^{*}$ which linearly depends on $x_{i}$ via a parameter vector $\beta$ and a normally distributed error term $u_{i}$ captures the random influence of this relation. The observed variable $y_{i}$ is equal to the latent variable if the latent variable is higher than zero but equals to zero if this is not the case.

$$
y_{i}=\left\{\begin{array}{l}
y_{i}^{*} \text { if } y_{i}^{*}>0 \\
0 \text { if } y_{i}^{*} \leq 0
\end{array}\right.
$$

where: $y_{i}^{*}$ is a latent variable which is equal to $y_{i}^{*}=\beta x_{i}+u_{i}$, and $u_{i} N\left(0, \sigma^{2}\right)$

Following Chebil et al. (2009), the likelihood function of the model (2) is given by $\mathrm{L}$ and it is presented as follows:

$$
\begin{aligned}
& L=\prod_{0} F\left(y_{0 i}\right) \prod_{1} f_{i}\left(y_{i}\right) \\
& L=\prod_{0}\left[1-F\left(x_{i} \beta / \sigma\right)\right] \prod_{1} \sigma^{-1} f\left[\left(y_{i}-x_{i} \beta\right) / \sigma\right]
\end{aligned}
$$

where $f$, and $F$ are the standard normal density and cumulative distribution functions, respectively. A log-likelihood function can be written as follows:

$$
\log L=\sum_{0} \log \left(1-F\left(x_{i} \beta / \sigma\right)+\sum_{1} \log \left(\frac{1}{\left(2 \prod \sigma^{2}\right)^{1 / 2}}\right)-\sum_{1} \frac{1}{2 \sigma^{2}}\left(y_{i}-\beta x_{i}\right)^{2}\right.
$$

The $\beta$ and $\sigma$ parameters are estimated by maximization of log-likelihood function 


$$
\left\{\begin{array}{l}
\frac{\partial \log L}{\partial \beta}=-\sum_{0} \frac{\left.x_{i} f\left(x_{i} \beta\right) / \sigma\right)}{1-F\left(x_{i} \beta / \sigma\right)}+\frac{1}{\sigma^{2}} \sum_{1}\left(y_{i}-\beta x_{i}\right) x_{i}=0 \\
\frac{\partial \log L}{\partial \sigma^{2}}=\frac{1}{2 \sigma^{2}} \sum_{0} \frac{\beta x_{i} f\left(x_{i} \beta / \sigma\right)}{1-F\left(x_{i} \beta / \sigma\right)}-\frac{n_{i}}{2 \sigma^{2}}+\frac{1}{2 \sigma^{4}} \sum_{1}\left(y_{i}-\beta x_{i}\right)^{2}=0
\end{array}\right.
$$

The Tobit model has been adopted in a number of studies (see, Taha, 2007; Rahmeto, 2007; Dereje, 2006). The empirical Tobit model $^{1}$ estimate is presented below:

$$
\begin{aligned}
Y_{i}= & \beta_{0}+\beta_{1} \text { YIELD }+\beta_{2} \text { SEACES }+\beta_{3} \text { ACREDIT }+\beta_{4} \text { AGE } 2+\beta_{5} \text { RICINC } \\
& +\beta_{6} \text { HSIZE }+\beta_{7} \text { GNR }+\beta_{8} \text { EXCONT }+\beta_{9} N C R I+\beta_{10} H O W N \\
& +\beta_{11} \text { MAIN }+\beta_{12} \text { NTRAIN }+\beta_{13} \text { OFFINC }+\beta_{14} \text { KANO }+\beta_{15} \text { NIGER } \\
& +\beta_{16} \text { TRAINB }+\beta_{17} \text { AGE }+\beta_{18} \text { MEORG }+\beta_{19} I N O C R P+\beta_{20} \text { TOTAREA } \\
& +\beta_{21} \text { SEDIST }+\beta_{22} \text { COSEED }+\beta_{23} \text { EDUB }+\beta_{24} \text { FYEXP }+v_{i}
\end{aligned}
$$

\section{Determinants of market participation and its effect on welfare: Heckman selection model}

In this study, a farmer is considered to participate in the output market if part of his/her rice output is marketed. Since one of the objectives of the study is to investigate the determinants of market participation and how it affects the welfare of rural farming households, we specified the basic relationship of the effect of market participation on welfare by the following regression model:

$$
G_{i}=X_{i}^{\prime} \lambda+\gamma D_{i}+\varepsilon_{i}
$$

Where:

$G_{i}=$ consumption expenditure per capita

$\varepsilon_{i}=$ normal random distribution term

$D_{i}=$ dummy $(1=$ commercialized; $0=$ not commercialized $)$ representing market participation. It takes the value of 1 if the farmer sells part of the rice output and 0 otherwise.

$X_{i}=$ vector of household and farm characteristics.

By deciding to participate in the market, the rice farmer self-selects to participate in the market instead of it being a random assignment. Therefore, following, we assume that the farmer is risk-neutral. The index function used to estimate market participation by the rice farmers can be expressed as:

$$
D_{i}^{*}=X_{i}^{\prime} \alpha+v_{i}
$$

$D_{i}^{*}=$ is a latent variable representing the difference between utility gained from market participation $U_{i A}$ and the utility from not participating in the market $U_{I N}$. The farmer will participate in the market if $D_{i}^{*}=U_{I A}-U_{I N}>0$.

The term $X_{i}^{\prime} \alpha$ provides an estimate of the difference in utility from market participation $\left(U_{I A}-U_{I N}\right)$ using the household and farm-level characteristics $X_{i}$, as explanatory variables, while $v_{i}$ is an error term.

In estimating equations (7) and (8), there is a need to note that the relationship between the market participation and farmers' welfare could be interdependent. Specifically, the selection bias occurs if unobservable factors influence both error terms of the welfare (per capita consumption expenditure) equation $\left(\varepsilon_{i}\right)$ and the market 
participation choice equation $\left(v_{i}\right)$, thus, resulting in the correlation between the error terms of the two equation (7 and 8). This implies that there are unobserved factors that bias the outcome on welfare as a result of market participation. Thus, estimating equation (7) using Ordinary Least Square (OLS) will lead to biased estimates. To address this problem, a two-step Heckman's procedure was used in this study. This model is appropriate because it addresses simultaneity problems.

In the literature, the Heckman (1976) two stage procedure is used to address selection bias when the correlation between the two error terms is greater than zero (Hoffman and Kassouf, 2005; Adeoti, 2009; Johannes et al. 2010; Siziba et al. 2011). The approach depends on the restrictive assumption of normally distributed errors (Wooldridge, 2002). The procedure involves, first, the estimation of the selection equation using a probit model (Market participation; equation (8)) and second, the estimation of the per capita consumption expenditure equation (7). The probit model predicts the probability of market participation and also gives the Inverse Mill's Ratio (IMR). IMR is denoted by a symbol $\lambda$ and describes the ratio of the ordinate of a standard normal to the tail area of the distribution (Greene, 2003):

$$
\lambda_{i}=\frac{\phi\left(\rho+\alpha X_{i}\right)}{\Phi\left(\rho+\alpha X_{i}\right)}
$$

Where $\phi$ and $\Phi$ are, respectively, the standard normal density function and standard normal distribution functions. The calculated IMR term $\lambda_{i}$ provides OLS selection corrected estimates (Greene, 2003). If $\lambda_{i}$ is not statistically significant, then sample selection bias is not a problem (Heckman, 1979; 1980). However, the finding of a statistically significant $\lambda_{i}$ in the welfare equation would suggest that an important difference exists between the farmers that participate in the market and those that did not participate. This difference needs to be taken into consideration in estimating the welfare equation. The Heckman two-step model $^{2}$ is specified as follows; the first step (selection equation) of deciding whether to participate in rice marketing or not is empirically specified as:

$$
\begin{aligned}
\text { MARKPAR }_{i}= & \alpha_{0}+\alpha_{1} \text { MEORG }+\alpha_{2} \text { VOCT }+\alpha_{3} \text { YEDUC }+\alpha_{4} \text { GNR }+\alpha_{5} A G E 2 \\
& +\alpha_{6} \text { AGE }+\alpha_{7} H S I Z E+\alpha_{8} \text { SEACES }+\alpha_{9} \text { RICINC }+\alpha_{10} \text { COSEED } \\
& +\alpha_{11} \text { ACREDIT }+\alpha_{12} \text { HOWN }+\alpha_{13} \text { OFFINC }+\alpha_{14} \text { TOTAREA } \\
& +\alpha_{15} \text { SEDIST }+\alpha_{16} \text { YIELD }+v_{i}
\end{aligned}
$$

The second step (outcome equation), which assesses the effect of market participation on the welfare of households (consumption expenditure per capita), is estimated empirically using OLS as follows:

$$
\begin{aligned}
G_{i}= & \gamma_{0}+\gamma_{1} \text { YIELD }+\gamma_{2} \text { EXCONT }+\gamma_{3} \text { GNR }+\gamma_{4} \text { VOCT }+\gamma_{5} \text { RICINC } \\
& +\gamma_{6} \text { COSEED }+\gamma_{7} \text { AGE } 2+\gamma_{8} \text { AGE }+\gamma_{9} \text { HSIZE }+\gamma_{10} \text { YRESID } \\
& +\gamma_{11} \text { YEDUC }+\gamma_{12} \text { HOWN }+\gamma_{13} \text { OFFINC }+\gamma_{14} \text { SEACES } \\
& +\gamma_{15} \text { ACREDIT }+\gamma_{16} \text { SEDIST }+\gamma_{17} \text { TOTAREA }+\gamma_{18} I M R+\varepsilon_{i}
\end{aligned}
$$

\section{Results and discussion}

Descriptive analysis

The distribution of socioeconomic/demographic characteristics of respondents (Tables 1 and 2) reveals that the average family size for sampled households consists of 8 persons 
Table 1 Variable definition and their descriptive statistics

\begin{tabular}{|c|c|c|c|}
\hline Variable & Description & Mean & Std.Dev. \\
\hline \multicolumn{4}{|c|}{ Dependent Variables } \\
\hline Y & IRVs area divided by the total farm size & 0.78 & 2.30 \\
\hline G & Per capita consumption expenditure & 34347.99 & 18226.89 \\
\hline MARKTPAR & 1 if farmer sell part of produce, 0 otherwise & 0.71 & 0.46 \\
\hline \multicolumn{4}{|c|}{ Independent Variables } \\
\hline YIELD & Average yield (Kg/ha) & 3271.07 & 2238.76 \\
\hline AGE & Age of household head & 45.00 & 8.62 \\
\hline AGE2 & Square of the age of household head & 2117.67 & 790.36 \\
\hline HSIZE & Number of person living in the household & 8.00 & 4.09 \\
\hline$E D \cup B$ & 1 if farmer has formal education, 0 otherwise & 0.68 & 0.47 \\
\hline VOCT & 1 if farmer attended vocational training, 0 otherwise & 0.15 & 0.36 \\
\hline GNR & 1 if household head is male, 0 if female & 0.81 & 0.40 \\
\hline OFFINC & 1 if farmer has non-farm income, 0 otherwise & 0.89 & 0.32 \\
\hline TOTAREA(HA) & Total farm size in hectare & 2.39 & 1.59 \\
\hline EXCONT & 1 if farmer has contact with extension agents, 0 otherwise & 0.36 & 0.48 \\
\hline HOWN & 1 if respondent is the landlord, 0 otherwise & 0.86 & 0.35 \\
\hline ACSEED & 1 if farmer has access to seed, 0 otherwise & 0.70 & 0.46 \\
\hline MEORG & 1 if farmer is a member of any organisation, 0 otherwise & 0.31 & 0.46 \\
\hline SECOST & The average cost of seed in Naira per kg & 124.97 & 1.56 \\
\hline INOCRP(N) & Average income from other crops & 90405.00 & 72470.89 \\
\hline RICINC & Income generated from the sale of rice & 189231.70 & 111276.60 \\
\hline SEDIST(KM)) & The distance from the village to the nearest sources of seed & 4.39 & 6.48 \\
\hline FUPL & 1 if farmer practice upland rice farming & 0.31 & 0.46 \\
\hline FLOWL & 1 if farmer practice lowland rice farming & 0.81 & 0.39 \\
\hline FIRRIG & 1 if farmer practice irrigated rice farming & 0.16 & 0.37 \\
\hline ACREDIT & 1 if farmer has access to credit & 0.24 & 0.42 \\
\hline YRESID & Years of residence in the village & 40.17 & 14.79 \\
\hline YEDUC & Years of formal education & 4.62 & 5.88 \\
\hline$N C R)^{a}$ & 1 if farmer has relationship with NCRI & 0.217 & 0.41 \\
\hline MAIN & 1 if the farming is the main occupation, 0 otherwise & 0.90 & 0.31 \\
\hline FYEXP & Years of farming experience & 37.12 & 11.32 \\
\hline TRAINB & 1 if farmer had attended any training, 0 otherwise & 0.21 & 0.41 \\
\hline NTRAIN & Number of training attended by the farmer & 3.00 & 2.70 \\
\hline
\end{tabular}

${ }^{a}$ NCRI National Cereal Research Institute

per household. The average age of the head of the household is 45 years and about $76 \%$ of them are below 50 years of age, with an average of 37 years of farming experience. This implies that the majority of the households were still young and in their productive age and are highly experienced in rice production. This could positively influence the adoption of IRVs as Polson and Spencer (1992) observed that younger household heads are more dynamic with regards to adoption of innovations. The farming households in the sampled area are male dominated as evidenced by $81 \%$ share of male household heads. The majority ( $88 \%$ ) of households in the sample acquired additional income from off-farm activities. About $68 \%$ of them received formal education. The proportions of the respondents that had contact with extension agents $(36 \%)$ and those that belong to 
Table 2 Description statistics of some socio-economic characteristics of the farmers

\begin{tabular}{|c|c|c|}
\hline Socio-Economic/Demographic characteristics & Frequency & Percentage \\
\hline \multicolumn{3}{|l|}{ Age of Household Head (Years) } \\
\hline $\begin{array}{l}20-30 \\
30-40 \\
40-50 \\
50-60 \\
60-70 \\
70-80\end{array}$ & $\begin{array}{l}30 \\
147 \\
252 \\
116 \\
13 \\
5\end{array}$ & $\begin{array}{l}5.33 \\
26.11 \\
44.76 \\
20.60 \\
02.30 \\
0.90\end{array}$ \\
\hline \multicolumn{3}{|l|}{ Household size (Number) } \\
\hline $\begin{array}{l}1-10 \\
10-20 \\
20-30\end{array}$ & $\begin{array}{l}429 \\
125 \\
9\end{array}$ & $\begin{array}{l}76.19 \\
22.20 \\
01.59\end{array}$ \\
\hline \multicolumn{3}{|l|}{ Farm Size $(\mathrm{Ha})$} \\
\hline $\begin{array}{l}1-1.5 \\
2-3.5 \\
4-5.5 \\
5-6.5 \\
\text { Mean Farm size }\end{array}$ & $\begin{array}{l}215 \\
206 \\
129 \\
13 \\
2.39\end{array}$ & $\begin{array}{l}38.19 \\
36.59 \\
22.91 \\
02.31\end{array}$ \\
\hline \multicolumn{3}{|l|}{ Rice Output (kg) } \\
\hline $100-1000$ & 67 & 11.01 \\
\hline $\begin{array}{l}1000-2000 \\
2000-3000 \\
3000-4000 \\
4000-5000 \\
5000-6000 \\
>6000 \\
\text { Mean output }\end{array}$ & $\begin{array}{l}78 \\
90 \\
164 \\
109 \\
31 \\
24 \\
3307.50\end{array}$ & $\begin{array}{l}13.85 \\
15.99 \\
29.13 \\
19.36 \\
05.51 \\
04.26\end{array}$ \\
\hline \multicolumn{3}{|c|}{ Proportion that participate in market by Rice Producing system } \\
\hline UplandLowlandlrrigated & $\begin{array}{l}153.00 \\
306.00 \\
89.00\end{array}$ & $\begin{array}{l}88.95 \\
66.81 \\
97.80\end{array}$ \\
\hline
\end{tabular}

Source: Field Survey, 2010

farmers' organization (31 \%) were below satisfactory levels. Only $15 \%$ attended agricultural vocational training. The average landholding size for the sampled households is 2.39 ha and about 1.7 ha is devoted to production of IRVs. In terms of household size, about $98 \%$ of the respondents had less than 20 persons. This predominantly large household size could be responsible for the small and fragmented farm size, such that a large percentage of the population $(75 \%)$ had farmland of less than 4 ha. The majority of the respondents (70 \%) harvested less than 4 tons of rice from their farms.

Farmers in the study area appear to be challenged in relation to seed access due to excessive distance to the nearest sources of seed. Only about $70 \%$ of the farmers have access to seed, and the seed can possibly be obtained by travelling an average distance of about $4.39 \mathrm{~km}$. This implies that a majority of the farmers will rely on their own saved seed, seed obtained from other farmers within the village or on seed purchased from the nearby rural market. This practice give rise to the use of low quality, uncertified and unimproved rice seed, with a negative effect on productivity. Results also illustrate that about $76 \%$ of respondents sold their product in the market.

The yields of improved and local/traditional rice varieties were compared by rice growing systems and the State. The results are presented in Table 3. Findings show expectedly that the yield of improved varieties is highest under the irrigated system, 
Table 3 Comparative assessment of rice yield for improved and traditional varieties

\begin{tabular}{lcc}
\hline Ecology/State & Average yield (kg/ha) & Standard error \\
\hline $\begin{array}{l}\text { Average Yield of Improved Rice Varieties by Production System and State } \\
\text { Rice production system }\end{array}$ & \\
Lowland & 2988.34 & 1721.54 \\
Upland & 3844.88 & 1625.56 \\
Irrigated & 4016.46 & 1698.92 \\
State & & \\
Niger & 2792.90 & 1488.11 \\
Osun & 2569.20 & 1719.94 \\
Kano & 4840.53 & 1712.12 \\
Average Yield of Local/Traditional Rice Varieties by Production System and State & \\
Rice production system & & \\
Lowland & 1223.30 & 992.02 \\
Upland & 1608.13 & 736.40 \\
State & & 1009.37 \\
Niger & 1229.69 & 144.68 \\
Osun & 950.17 & \\
\hline Source:Fid Suvey 2010 & & \\
\hline
\end{tabular}

Source: Field Survey, 2010

followed by the upland system and the lowest yields were obtained in lowland rice producing systems in Nigeria. This links to the fact that agricultural production generally in Nigeria is rain-fed and output is greatly determined by the amount of rainfall. An irrigated rice producing system usually has enough water supply all year round. In addition, some of the high yielding, disease resistance varieties released were mostly upland varieties. However yield in lowland rice producing system is believed to be low due to the high rates of attack by pests and diseases and the heaviness of the soil as a result of its high water retention capacity, which requires high levels energy for cultivation (and this applies to man and machine) - working these heavy soils is tedious and highly labour intensive. The selected States were also representatives of rice growing systems. Therefore, it is not surprising that the yield per State seemingly followed the same pattern as that of the producing systems. Kano has the highest yield, because rice production in Kano State is mostly irrigated. In the same vein Osun and Niger are upland and lowland dominated rice growing systems, respectively. In terms of market participation by rice producing system, the results show that almost all the farmers in irrigated rice producing system $(98 \%)$ participate in rice marketing. This could be due to the high potential yield year after year as a result of irrigation.

Furthermore, Table 3 also shows that irrigation is not usually used for the production of traditional rice varieties in Nigeria. Generally, the results show that the yield of traditional varieties is extremely low compared with that of the improved varieties. The traditional upland rice varieties surpass the yield of the lowland varieties. The finding about the generally low yields of traditional varieties, therefore, justifies the dissemination and encouragement of the adoption of IRVs for increasing rice yields to meet national food requirement and ensure households' food security in Nigeria in particular and in Africa as a whole. In addition, due to this observed yield increase for the improved varieties, it is also expected that the adopters of improved varieties should 
be better off compared with the non-adopters - as measured by means of certain welfare improving indicators.

Notably, the analysis presented in Table 4 revealed significant differences in key variables between farmers that adopted IRVs and those that still planted the traditional varieties. The adopters had a significantly higher consumption expenditure per capita, higher rice income per hectare, higher rice income per capita, greater total farm income per capita, better average yield, larger farm size, and they were able to obtain credit more readily than the non-adopters. Additionally, it was discovered that there is no significant difference in the cost of seed for the adopters and non-adopters. Relative to the traditional varieties, based on the better qualities IRV is adjudged to be 'cheaper' than the traditional varieties. However, an additional cost for the adopters is the cost of transportation from the nearest sources of seed. This is because - unlike for the traditional varieties - the improved seeds are not always readily available in those market outlets near to the farmers. However, programs such as the Emergency rice initiative sponsored by USAID made the improved seed available to the rice farmers at a subsidised rate; in addition, the Federal Government of Nigeria also subsidize the purchase of high quality seed under the national agricultural inputs subsidy program.

In the same vein, comparison between market participants and non-participants, presented in Table 5, also revealed significant differences in key welfare indicator variables. Farmers that participated in markets had higher and significant consumption expenditure per capita, rice income per capita, average yield and have access to credit than the farmers who did not participate in markets.

\section{Determinants of intensity of adoption of improved rice varieties}

Prior to the estimation of the Tobit and Heckman two-step models the variables included in the models were tested for multi-collinearity using the correlation coefficient. We did not find any problem of multi-collinearity among all the explanatory variables. The factors that influence the intensity of IRVs adoption was assessed using the Tobit model. Four separate regressions were run - one for the pooled data and one each for the rice producing system (upland, irrigated and lowland). The choice of the independent variables included in the model was based on economic theory and literature review. The results of the Tobit estimates for the pooled data, upland, lowland and irrigated rice systems are presented in column 1, 2, 3, and 4, respectively of Table 6. All the models are well fitted and the results show that except for the irrigated system, over $20 \%$ of the variation in the extent of IRVs adoption is explained by the independent variables.

The yield (YIELD) of rice and being a member of any organization (MEORG) is positive and statistically significant in determining the magnitude of IRVs adoption in the pooled data. Thus, an increase in these variables will lead to an increase in the degree of IRVs adoption. For example, an increase in yield is expected to translate into an increase in income, which is important not only for the purchase of production inputs but also for acquiring more land, more hired labour and for other non-productive assets that could help expand rice farming. In the same vein, membership of an organization, which is regarded as one of the most important components of social capital, is expected to improve farmers' access to appropriate information about the 
Table 4 Mean difference in some welfare indicators between adopters and non-adopters of improved rice varieties

\begin{tabular}{|c|c|c|c|c|c|}
\hline Variable & All & Adopters $(N=348)$ & Non-adopters $(N=215)$ & Difference & t-value \\
\hline Consumption expend. per capita & $21897.78(954.84)$ & $23201.19(1117.76)$ & $19788.07(1719.63)$ & $3413.12(1961.78)$ & $1.74^{*}$ \\
\hline Rice income per hectare & $223555.90(6109.67)$ & $231268.30(8063.61)$ & $211072.70(9212.44)$ & 20195.59 (12557.55) & 1.61 \\
\hline Rice income per capita & $28503.33(1054.86)$ & $32500.24(1860.09)$ & $26033.81(1245.49)$ & $6466.44(2155.88)$ & $2.99^{* * *}$ \\
\hline Total farm income per capita & $43188.73(1607.10)$ & $42775.88(1796.17)$ & $43856.98(3048.06)$ & $1081.11(3310.46)$ & 0.33 \\
\hline Average yield (kg/ha) & $3271.07(94.35)$ & $3408.13(122.6)$ & $3049.22(146.57)$ & $358.90(193.78)$ & $1.85^{*}$ \\
\hline Total farm size (ha) & $2.59(0.09)$ & $2.63(0.12)$ & $2.55(0.16)$ & $0.08(0.19)$ & 0.39 \\
\hline Access to credit (\%) & $23.45(0.02)$ & $12.07(0.02)$ & $41.86(0.03)$ & $29.79(0.03)$ & $8.61^{* * *}$ \\
\hline Market participation (\%) & $70.69(0.02)$ & $60.63(0.03)$ & $86.97(0.02)$ & $26.34(0.04)$ & $6.94^{* * *}$ \\
\hline Cost of seed $(N)$ & $124.97(1.56)$ & $124.71(1.49)$ & $125.39(1.82)$ & $0.684(2.38)$ & 0.287 \\
\hline Distance to source of seed (KM) & $4.39(0.27)$ & $5.36(0.39)$ & $2.80(0.29)$ & $2.56(0.55)$ & 4.61 \\
\hline
\end{tabular}

Source: Field survey, $2010 .{ }^{* * *}, * *$, and ${ }^{*}$ implies significant at $1 \%, 5 \%$, and $10 \%$ respectively

Note: Figures in Parentheses are the standard error 
Table 5 Mean difference in some welfare indicators between market participants and non-participants

\begin{tabular}{|c|c|c|c|c|c|}
\hline Variable & All & Market participants $(N=398)$ & Non-market participants $(N=165)$ & Difference & t-value \\
\hline Consumption expend. per capita (N) & $21897.78(954.84)$ & $27015.49(2474.14)$ & $19776.11(859.47)$ & $7239.38(2077.27)$ & $3.49^{* * *}$ \\
\hline Rice income per hectare $(\mathrm{N})$ & $223555.90(6109.67)$ & $242161.20(7584.32)$ & $178677.80(9122.47)$ & $63483.32(13164.66)$ & $4.82^{* * *}$ \\
\hline Rice income per capita $(\mathrm{N})$ & $28503.33(1054.86)$ & $31107.86(1401.26)$ & $22220.53(1097.74)$ & $8887.84(2289.01)$ & $3.88^{* * *}$ \\
\hline Total farm income per capita (N) & $43188.73(1607.10)$ & $45329.88(2168.30)$ & $38024.03(1586.53)$ & $7305.85(3520.42)$ & $2.08^{* *}$ \\
\hline Average yield (kg/ha) & $3271.07(94.35)$ & $3587.00(118.42)$ & $2509.06(131.13)$ & $1078.00(202.42)$ & $5.33^{* * *}$ \\
\hline Total farm size (ha) & $2.59(0.09)$ & $2.47(0.11)$ & $2.91(0.16)$ & $0.45(0.20)$ & $2.21^{* *}$ \\
\hline Access to credit (\%) & $23.45(0.02)$ & $28.14(0.02)$ & $12.12(0.03)$ & $16.02(0.04)$ & $4.14^{* * *}$ \\
\hline
\end{tabular}

Source: Field survey, 2010. *****, and * implies significant at $1 \%, 5 \%$, and $10 \%$ respectively

Note: Figures in Parentheses are the standard error 
Table 6 Determinants of intensity of adoption of improved rice varieties: Tobit model

\begin{tabular}{|c|c|c|c|c|}
\hline & Pooled data (1) & Upland (2) & Lowland (3) & Irrigated (4) \\
\hline Variable & Coefficient & Coefficient & Coefficient & Coefficient \\
\hline$\overline{Y I E L D}$ & $0.0001 *(0.000)$ & $0.000(0.000)$ & $-0.0001(0.000)$ & $-0.000(0.000)$ \\
\hline SEACES & $-0.185(0.127)$ & $-0.420^{* *}(0.203)$ & $-0.333^{*}(0.171)$ & $-0.053(0.055)$ \\
\hline ACREDIT & $-0.243^{*}(0.144)$ & $-0.022(0.129)$ & $-0.353^{*}(0.183)$ & $0.084(0.059)$ \\
\hline AGE2 & $0.001^{* *}(0.000)$ & $0.001^{*}(0.001)$ & $0.001^{*}(0.001)$ & $-0.000(0.000)$ \\
\hline RICINC & $0.179^{*}(0.092)$ & $0.355^{* * *}(0.093)$ & $0.349^{* *}(0.116)$ & $0.100^{* *}(0.047)$ \\
\hline HSIZE & $0.023(0.015)$ & $-0.012(0.019)$ & $0.025(0.021)$ & $-0.005(0.005)$ \\
\hline GNR & $0.089(0.152)$ & $-0.189(0.324)$ & $0.124(0.196)$ & $0.048(0.058)$ \\
\hline EXCONT & $-0.366^{* *}(0.152)$ & $0.315(0.399)$ & $-0.448^{* *}(0.227)$ & $-0.015(0.036)$ \\
\hline$N C R I$ & $-1.379^{* * *}(0.229)$ & $0.709(0.635)$ & $-1.481^{* * *}(0.306)$ & $-0.067(0.181)$ \\
\hline HOWN & $0.864^{* * *}(0.247)$ & $0.524(0.347)$ & $0.747^{* *}(0.325)$ & - \\
\hline MAIN & $-0.033(0.208)$ & $0.126(0.214)$ & $0.092(0.252)$ & $0.105(0.179)$ \\
\hline NTRAIN & $-0.062(0.039)$ & $-0.012(0.035)$ & $-0.149 *(0.081)$ & $0.007(0.007)$ \\
\hline OFFINC & $-0.126(0.213)$ & $0.294(0.319)$ & $-0.088(0.269)$ & - \\
\hline KANO & $0.372^{* *}(0.179)$ & $0.764(0.529)$ & $1.068(0.839)$ & - \\
\hline NIGER & $-0.626^{* * *}(0.175)$ & $0.508(0.424)$ & - & $0.088(0.128)$ \\
\hline TRAINB & $0.349^{*}(0.186)$ & $0.061(0.290)$ & $0.718^{* *}(.297)$ & $-0.037(0.043)$ \\
\hline AGE & $-0.102^{* * *}(0.038)$ & $-0.087^{*}(0.049)$ & $-0.120^{* *}(0.049)$ & $0.004(0.018)$ \\
\hline MEORG & $0.231^{*}(0.129)$ & $0.132(0.188)$ & $0.253(0.177)$ & $0.062(.038)$ \\
\hline INOCRP & $0.338^{* * *}(0.077)$ & $-0.156^{*}(0.088)$ & $0.445^{* * *}(0.110)$ & $0.031(0.034)$ \\
\hline TORAREA & $-0.021(.033)$ & $-0.015(0.045)$ & $-0.028(0.045)$ & $-0.103^{* * *}(0.013$ \\
\hline SEDIST & $0.017^{* *}(0.008)$ & $0.008(0.011)$ & $0.028^{*}(0.015)$ & $0.001(0.002)$ \\
\hline COSEED & $0.008^{* * *}(0.002)$ & $0.009^{* * *}(0.004)$ & $0.008^{* * *}(0.003)$ & $-0.001(0.002)$ \\
\hline$E D \cup B$ & $-0.295^{* *}(0.118)$ & $0.093(0.145)$ & $-0.339^{* *}(0.148)$ & $-0.020(0.072)$ \\
\hline FYEXP & $0.009(0.008)$ & $0.016(0.010)$ & $-0.007(0.008)$ & $-0.003(0.002)$ \\
\hline CONSTANT & $-3.834^{* * *}(1.383)$ & $-2.655(1.643)$ & $-6.131(1.841)$ & $-0.448(0.579)$ \\
\hline ISIGMA & $0.948(0.039)$ & $0.549(0.046)$ & $1.118(0.054)$ & $0.104(0.008)$ \\
\hline NUMBER OF OBSERVATION & 514.000 & 151.000 & 417.000 & 90.000 \\
\hline LR CHI2 (24) & 279.060 & 72.640 & 226.340 & 91.090 \\
\hline$P R O B>C H I 2$ & 0.000 & 0.000 & 0.000 & 0.000 \\
\hline PSEUDO R2 & 0.204 & 0.239 & 0.203 & 0.058 \\
\hline LOG LIKELIHOOD & -543.670 & -115.773 & -443.737 & -74.301 \\
\hline
\end{tabular}

Source: Field survey, 2010. ${ }^{* * *}$, **, and * implies significant at $1 \%, 5 \%$, and $10 \%$ respectively Note: Figures in Parentheses are the standard error ME Marginal Effect

IRVs, and hence to have a positive effect on adoption. This is expected to increase the financial capability of farmers and therefore, to allow for higher levels of IRVs adoption. This finding is also in tandem with other findings such as those of Bamire et al. (2002), and Ojiako et al. (2007). In addition, it further substantiated the notion that it will be possible for agricultural development agencies to achieve greater success when they co-operate with farmer organisations (Verteeg and Koudokpon, 1993).

Income from rice production (RICINC) is positively and statistically significant in the pooled data, and among all the farmers that produce within the upland, lowland and irrigated rice producing systems. This suggests that as income from rice production 
increases, the degree of adoption of IRVs also increases. This could be explained by the fact that an increase in the area devoted to planting of IRVs will require additional funds (income or credit) to purchase the necessary inputs such as fertilizer, herbicides and to pay for hired labourers. Therefore, farmers with higher income are more likely to increase the area devoted to IRVs. Similarly, income from other crops (INOCRP) is also positive and statistically significant in the pooled data and among the lowland farmers, but this negatively influences the intensity of IRVs adoption among the upland rice farmers. The negative influence of income from other crops on the intensity of IRVs adoption among the upland rice farmers could be due to the fact that cultivation of other crops competes with rice for land space and other necessary inputs and therefore causes a reduction in the land devoted to IRVs adoption.

Ownership of a house (HOWN), which is a measure of wealth is positive and statistically significant in determining the intensity of IRVs adoption in the pooled data and among the farmers that practice lowland rice production. This findings show that the farmers that are landlords are more likely to devote a large portion of their farmland to the cultivation of IRVs. Attending at least one training session (TRAINB) is also positive and statistically significant in influencing the intensity of IRVs adoption in the pooled data and among the lowland rice producing farmers. However, the number of training sessions attended (NTRAIN) has a negative and statistically significant effect on the intensity of IRVs adoption among the lowland farmers.

Distance to the nearest sources of seed (SEDIST) is positive and statistically significant in determining the intensity of IRVs adoption in the pooled data and among the lowland rice farmers. Similarly, the coefficient for cost of rice seed (SECOST) is positively and statistically significant in determining IRVs adoption in the pooled data for both the upland and lowland farmers. Distance to the nearest sources of seed in kilometre is an indication of how easily accessible the seed of IRVs is to farmers. The findings reveal that as the distance to the nearest seed source increases, the probability that a farmer would increase the intensity of adoption of IRVs also increases. Long distance may mean high transportation cost and this could make the farmers wish to cultivate more rice in order to be able to save enough seed from their own harvest for planting the following years. This suggests that the lack of availability of IRVs within the farmers' localities could encourage the use of farmers' own preserved seed, use of poor quality IRVs and ultimately lead to lower productivity. Furthermore, as the cost of the seed increases, farmers devote more land to the production of IRVs. This finding could be a pointer to the fact that most rice farmers are also seed sellers and the primary aim of rice production may not only be to sell the paddy as food, but also as seed particularly in the rural areas where rural agro-dealers are in short supply or where farmers need to travel long distance to buy seed. Therefore, this is in line with the basic economic principle which states that the higher the price, the higher the quantity supplied. Farmers will want to produce more by increasing the proportion of the land cultivated to rice, in other to be able to sell more and make more money as the seed price increases.

In the pooled data, the farmers from Kano (KANO), an irrigated rice producing area, devote more land to IRVs than farmers from other locations. In addition, intensity of IRVs adoption is higher among those farmers without education (EDUB), access to credit (ACREDIT), contact with extension agents (EXCONT) and relationship with 
NCRI (NCRI) in the pooled data and among the lowland farmers. This implies that the proportion of farmland devoted to the cultivation of IRVs is higher among the noneducated farmers compared to the educated ones. The educated farmers are more likely to participate in other secondary activities such as wage employment, private business activity or mining which can limit the time available for farming and hence, have a negative effect on the intensity of their adoption of IRVs. The negative and statistically significance of the coefficient of access to credit (ACREDIT) suggests that intensity of adoption of IRVs is higher among those farmers that lack access to credit. It is worthy of note that the majority of rural farmers in Nigeria are credit constrained. Hence, intensive production of IRVs through devoting more land to it may enhance financial stability, especially in times of need.

Furthermore, in this study we observed a negative, but increasing effect of age (AGE) on market participation. The negative and significant coefficient of age of household head implies that older households are less likely to increase the intensity to which they adopt IRVs. This may be because they are less receptive to new ideas and are less willing to take risks associated with new innovations as are the younger farmers (Roger, 1983; Alavalapati et al. 1995). Risk aversion has been found in the literature to be a major constraint to technology adoption in developing countries (Eswaran and Kotwal 1990; Rosenzweig and Binswanger, 1993; Dercon and Christiaensen, 2007; Yesuf et al. 2009). This finding about risk aversion is in agreement with other studies such as Itana (1985), Hassan et al. (1998), Alene et al. (2000), Kaguongo et al. (2010) and Awotide et al. (2014). However, the positive and statistical significance of the coefficient of age squared (AGE2) implies that the age of the farmers will decrease adoption to a certain level and then intensity of adoption will start to increase.

It is also remarkable to observe that the intensity of IRVs adoption decreases as farmland (TOAREA) increases only among the farmers that practice irrigation. This suggests that those who have larger farm size among the irrigation farmers devote less of their farmland to the cultivation of IRVs. On the one hand, this could be linked to the fact that some households may not want to experiment with new technologies on large farmlands because of uncertainty. On the other hand, it could be due to the fact that farmers with large farm size may want to maximise profit and hence, are more likely to practice multiple cropping from the available farmland. This is consistent with the finding of Shiyani et al. (2002), who reported a negative relationship between farm size and level of adoption of improved varieties and fertilizer and Awotide et al. (2014) on intensity of adoption of improved cassava varieties in south-western Nigeria.

\section{Market participation and welfare: Heckman two-step model}

A multivariate analysis was adopted to evaluate the effect of market participation on households' welfare using Heckman's two-step model. The dependent variable of the market participation model (Selection model) was specified as binary, which is equal to 1 if the farmers sell part of their rice output, and 0 otherwise. The second stage of the Heckman two-stage model estimates the factors that determine households' welfare proxy by the annual consumption expenditure per capita and also tests if there is selection bias by inserting the lambda obtained from the Probit model. Membership of a farm organization was used as the identification variable. This variable is assumed to 
affect the probability of participation in rice output markets, but is assumed not to influence the farmers' welfare. The overall joint goodness of fit for the Heckman selection model parameter estimates was assessed. The diagnostic statistics shows that all of the estimated three models are well fitted with chi-square test statistics significant at $1 \%$. This implies that jointly the independent variables included in the selection models are relevant in explaining the farmers' market participation decision and welfare.

The results of the Heckman two-step model for the selection and the outcome equations are presented in Table 7. In order to ascertain differences in the factors that influence the determinants of market participation and its effect on welfare. We have also run four different models - one for the pooled data and other models for the upland, lowland and irrigation farmers. Interestingly, we found the regression for the sub-population of the farmers that practice irrigated rice farming spurious. This is due to the fact that almost all the farmers $(98 \%)$ in the irrigated farming households participated in the rice output market, thus there is no variation in the dependent variable. The results of the Heckman two-step model for the pooled data, upland and lowland rice producing system are presented in column 1, 2, and 3 of Table 7, respectively. Findings showed that out of the 18 variables included in the market participation equation, 13, 5, 10 were statistically significant (positive and negative) for the pooled data, the upland and the lowland farming households, respectively.

The gender (GNR) of the household head has Positive and statistically significant coefficients in the pooled data, upland and lowland farming households. This result implies that the probability that they would participate in the market is higher among the male headed households than the female counterparts. This could be due to the fact that the male headed households tend to have larger output than the female headed households as a result of their better access to productive inputs. Vigneri and Vargas (2011) revealed that women rarely had similar access to assets and markets as men, which led to a different level of participation in cash crop markets. Chikuvire et al. (2006) reported that women in SSA are disadvantaged in marketing because of unequal distribution of resources as well as cultural barriers. Dorward et al. (2004) also concluded that the discriminatory tendencies towards women tend to weaken their negotiation talent and therefore making them less effective in ago-commodity trade. In addition, women also spend much of their time doing house work and allocate less time to other matters like market transactions (Wang'ombe, 2008). This finding is similar to the finding of Cunningham et al. (2008), Wang'ombe (2008), Sigei et al. (2013) and Sebatta et al. (2014). However, this finding is different from that of Onoja et al. (2012) in which they found a higher probability of fish commercialization if the head of the household is female.

The coefficient of the years of formal education (YEDUC) was also positive and statistically significant in the pooled data and among the lowland farming households. This means that a higher level of education is associated with increased sales of rice. Makhura et al. (2001) reported that the educational level of the household head will have an effect on households' understanding of market dynamics and hence can enhance the farmers decision about the quantity of output sold, inter alia. This finding is in agreement with the finding of Martey et al. (2012), Enete and Igbokwe (2009), Randela et al. (2008) who are of the opinion that education of the household head has 
Table 7 Result of the Heckman two-step model

\begin{tabular}{|c|c|c|c|}
\hline & Pooled data (1) & Upland system (2) & Lowland system (3) \\
\hline Variable & Coefficient & Coefficient & Coefficient \\
\hline \multicolumn{4}{|c|}{ Effect of Market Participation on Welfare: Outcome Equation-OLS } \\
\hline YIELD & $1.182^{* *}(0.571)$ & $-1.2503(0.8632)$ & $0.8636(0.6168)$ \\
\hline EXCONT & $1577.404(2522.187)$ & $9733.857(6310.524)$ & $-2477.328(4412.423)$ \\
\hline GNR & $17033.220^{* * *}(3305.896)$ & $23811.81^{* * *}(5882.429)$ & $16028.38^{* * *}(3289.288)$ \\
\hline VOCT & $6154.037^{* *}(3006.475)$ & $6707.037(5754.729)$ & 1002.409 (3375.999) \\
\hline RICINC & $0.017^{*}(0.009)$ & $0.0661^{* * *}(0.0163)$ & $0.0221^{* *}(0.0104)$ \\
\hline COSEED & $7.753(47.103)$ & $-9.0323(68.8715)$ & $24.76333(47.5518)$ \\
\hline AGE2 & $14.295^{*}(8.606)$ & $-6.2775(4.9782)$ & $13.9342(8.9275)$ \\
\hline AGE & $-1458.261^{*}(795.262)$ & $822.0033(373.587)$ & -989.1075 (855.5659) \\
\hline HSIZE & $-2194.872^{* * *}(309.838)$ & $-2613.632^{* * *}(504.914)$ & $-2599.768^{* * *}(427.7767)$ \\
\hline YRESID & $210.599^{* *}(82.123)$ & $-50.5019(228.7992)$ & $209.3046^{* *}(94.1272)$ \\
\hline YEDUC & $644.065^{* * *}(165.175)$ & $130.358(217.61)$ & $759.556^{* * *}(244.9649)$ \\
\hline HOWN & 3593.435 (3504.657) & 12928.19 (9626.319) & 3786.609 (3662.154) \\
\hline OFFINC & $6124.644^{*}(3411.996)$ & $2027.904(7291.49)$ & $8152.286^{* *}(3957.274)$ \\
\hline SEACES & $4642.414(3554.374)$ & $-2443.123(5420.077)$ & 2981.639 (3392.325) \\
\hline ACREDIT & $-2291.433(2228.743)$ & 3121.345 (3700.875) & $504.0302(2638.233)$ \\
\hline SEDIST & 99.407 (158.767) & $-304.55(281.2507)$ & 32.52597 (254.5398) \\
\hline TOTAREA & $-179.980(455.375)$ & 175.0563 (877.4499) & $810.1287(533.2662)$ \\
\hline CONSTANT & $47485.940^{* *}(23754.530)$ & $4070.513(32750.9)$ & $36323.91(24493.74)$ \\
\hline Mills Lambda & $15272.930^{* *}(6612.894)$ & $17344.93 *(9388.366)$ & $12547.09^{*}(7334.769)$ \\
\hline \multicolumn{4}{|c|}{ Determinants of Market Participation: Probit Model } \\
\hline MEORG & $-0.504^{* * *}(0.172)$ & $-0.6321(0.7890)$ & $-0.3546^{*}(0.1992)$ \\
\hline EXCONT & $-0.341^{* *}(0.165)$ & $-0.5191(0.9021)$ & $-0.8787^{* * *}(0.2050)$ \\
\hline VOCT & $-0.442^{* *}(0.193)$ & $-2.8322^{* *}(1.3907)$ & $-0.3375(0.2339)$ \\
\hline YEDUC & $0.023^{*}(0.013)$ & $0.1591(0.1271)$ & $0.0332^{* *}(0.0163)$ \\
\hline GNR & $0.666^{* * *}(0.176)$ & $3.0568^{* *}(1.2142)$ & $0.5249^{* * *}(0.2016)$ \\
\hline AGE2 & $-0.001(0.001)$ & $-0.0016(0.0020)$ & $-0.0004(0.0005)$ \\
\hline AGE & $0.072(0.047)$ & $0.1184(0.2049)$ & 7.49E-02 (5.07E-02) \\
\hline HSIZE & $-0.063^{* * *}(0.019)$ & $0.1113(0.1474)$ & $-0.1132^{* * *}(0.0243)$ \\
\hline YRESID & $-0.0025(0.0664)$ & $-0.0128(0.0283)$ & $-0.0061(0.0075)$ \\
\hline SEACES & $0.971^{* * *}(0.150)$ & $1.1562(0.7573)$ & $0.8023^{* * *}(0.1741)$ \\
\hline RICINC & $1.32 \mathrm{E}-06^{*}(7.99 \mathrm{E}-07)$ & $-3.03 \mathrm{E}-06(4.41 \mathrm{E}-06)$ & 1.86E-07(9.79E-07) \\
\hline COSEED & $0.011^{* * *}(0.003)$ & $-0.0060(0.0158)$ & $0.0042261(0.0039)$ \\
\hline ACREDIT & $0.353^{*}(0.186)$ & $0.0927(0.8604)$ & $0.6325^{* * *}(0.2040)$ \\
\hline HOWN & $0.312(0.257)$ & $2.1323^{* *}(1.0402)$ & $0.1723(0.2997)$ \\
\hline OFFINC & $-0.537^{*}(0.276)$ & $-2.7412^{* *}(1.3619)$ & $-0.8467^{* * *}(0.3119)$ \\
\hline TOTAREA & $0.003(0.042)$ & $0.1239(0.1607)$ & $0.0696(0.0498)$ \\
\hline SEDIST & $-0.026^{*}(0.011)$ & $-0.0306(0.0325)$ & $-0.0411^{* * *}(0.0135)$ \\
\hline YIELD & $0.000^{* * *}(0.000)$ & $0.0007^{* *}(0.0003)$ & $0.0002^{* * *}(0.0000)$ \\
\hline CONSTANT & $-3.672^{* * *}(1.235)$ & $-3.8903(5.8576)$ & $-2.2379(1.3921)$ \\
\hline $\mathrm{RHO}$ & 0.881 & 1.0000 & 0.78613 \\
\hline SIGMA & 17344.686 & 17344.934 & 15963.17 \\
\hline
\end{tabular}


Table 7 Result of the Heckman two-step model (Continued)

\begin{tabular}{llll}
\hline Number of observations & 557.000 & 170.000 & 454.000 \\
Censored observations & 161.00 & 18.000 & 150.000 \\
Uncensored observations & 396.00 & 152.000 & 304.000 \\
Wald chi2 (17) & 142.40 & 93.680 & 99.480 \\
Prob > chi2 & 0.0000 & 0.0000 & 0.0000 \\
\hline
\end{tabular}

Source: Field survey, 2010. ${ }^{* * *}$, **, and * implies significant at $1 \%, 5 \%$, and $10 \%$ respectively Note: Figures in Parentheses are the standard error

the capacity to provide the farmer with a better production and managerial ability which lead to an increase in market participation

The coefficient of access to seed (SEACES) and credit (ACREDIT) was positive and statistically significant in the pooled data and among the lowland rice farming households. This suggests that increase in access to improved seed varieties would also lead to increase in the probability that a farmer would participate in market. It is noted that adoption of improved seed will be impossible without access to such seed (Dontsop-Nguezet et al. 2012). Hence, access to seed will aid adoption and adoption is expected to generate increase in output leading to increase in marketable surplus. The higher profits generated from output grown from IRVs, will further encourage the farmers to participate in market. In the same vein, access to credit increases the probability that a farmer will participate in the market. This could be due to the fact that access to credit enables the farmers to cover labour cost, transportation cost and all other production related costs. Hence, the farmers that have access to credit have higher chances of having marketable surplus to sell than those that did not have access to credit. This result is consistent with the findings of Alene et al. (2007) and Abayneh and Tefera (2012).

Yield (YIELD) is positive and statistically significant in the pooled data and among the upland and lowland rice farming households. The positive coefficient of rice yield signifies that an increase in yield, increases the probability that a farmer will participate in the market. In other words, increase in yield will increase the households' marketable surplus. This result is consistent with the findings of Omiti et al. (2009), Astewel (2010) and Olwande and Mathenga (2010) who report that increase in the quantity of production will increase the likelihood of market participation. In the same vein, Abay (2007) and Adugna (2009) also found that an increase in the yield of tomato and papaya significantly increase their marketable surpluses.

Cost of seed (COSEED) and income from rice production (RICINC) was positive and statistically significant only in the pooled data. This implies that as the price of seed and income from rice production increase, the farmers are motivated to participate more in the market. Similarly, the coefficient of house ownership (HOWN) - a measure of wealth - was also positive and statistically significant in the sub-population of the upland rice farming households. The coefficient of off-farm income (OFFINC) was also negative and statistically significant in the pooled data and sub-population of the upland and lowland rice farming households. Participating in any secondary occupation generally discourages households from participating in the market. Those who have income from off-farm activities generally do not have enough time to engage in the market activities. This implies that off-farm income has the tendency to initiate 
off-farm diversification. Jaleta et al. (2009) posited that ownership of livestock, which is usually one of the major sources of off-farm /non-arable income, negatively influence households' participation in the crop market as a result of the possibility of distraction away from farming. This finding is consistent with the findings by Alene et al. (2008), Omiti et al. (2009) and Martey et al. (2012).

Similarly, coefficient of membership of any organization (MEORG) and contact with extension agents (EXCONT) were also negative and statistically significant in the subpopulation of the upland rice farming households. However as contact with extension agents increases, the probability that a farmer would participate in the market decreases. This could be due to the fact that the primary function of the extension agents in Nigeria is mainly limited to the dissemination of IRVs and training of farmers on the best-bet production technologies. Essentially, their contact with the farmers may be only to encourage adoption of IRVs and may not have anything to do with linking farmers to the markets or encouraging them to participate in output markets. The negative and significant coefficient of MEORG implies that farmers that belong to farmers' organizations participate less in rice output market. This finding is in agreement with the finding of Martey et al. (2012) in their study on commercialization of smallholder agriculture in Ghana, but contradicts the findings of Matungul et al. (2001), Olwanda and Mathenge (2012) and Musah et al. (2014).

In the same vein, being a member of any organization (MEORG) is regarded is a form of social capital. The results show that those farmers that are not members of any organization are more likely to participate in rice markets than those who are members. This implies that membership of any organization decreases the probability of market participation. This may be explained by the fact that most farmers' organizations in Nigeria are not market oriented. Basically, they focus more on credit access and input distribution. This finding is consistent with the finding of Abayneh and Tefera (2013), but it is contrary to the findings of other studies such as Jagwe (2011) and Sebatta et al. (2014) which found that belonging to a farmer's group significantly influenced the extent of farmers' participation in Banana and potato markets, respectively. Similarly, Shepherd (2007) also suggested that collective action by means of a farmer cooperative society increases smallholder market participation.

The coefficient of vocational training (VOCT) was also negative and statistically significant in the pooled data and sub-population of the upland rice farming households. Those farmers that attended vocational training are also more likely to have other sources of income apart from rice production and so may not be really interested in participating in the markets.

The coefficients of household size (HSIZE) and distance to the nearest sources of seed (SEDIST) were also negative and statistically significant in the pooled data and sub-population of the lowland rice farming households. Large household size reduces the probability that a farmer will participate in the market. This could be due to the fact that large household size has the tendency to reduce the marketable surplus, as more of the rice output would be consumed within the household since rice is the most important staple food crop in the Nigerian diets. This is in line with the findings of Mekhura et al. (2001) and Siziba et al. (2011). In the same vein, distance to the seed source is an indication of travel time and transportation cost and as these increase, farmers may not find it worthwhile to sell all their paddy rice, but rather prefer to keep 
some as seed for next season planting. This attitude will therefore probably decrease market participation. This finding confirms the findings of Omiti et al. (2009), Martey et al. (2012) and Musah et al. (2014).

The second stage (OLS outcome model) involved examination of the effect of market participation on welfare. The IMR for all the estimated models for the pooled data, upland and lowland farmers was positive and significant, which implies that the error terms in the selection and the outcome equations are positively correlated, hence unobserved factors that make participation more likely tend to be associated with higher household welfare. This indicates that sample selection bias is a problem and it therefore justifies the use of the Heckman two-step model. The result further suggests that any increase in the farmers' welfare (consumption expenditure per capita) is conditional on the probability of the farmer participating in the output market.

The coefficient of gender (GNR) of household head is statistically significant in the pooled data, among the sub-population of the upland and lowland rice farming households. This implies that the male headed households have better welfare than the female headed households. The positive and statistically significant coefficients of yield (YIELD) and vocational training (VOCT) in the pooled data suggest that welfare of the farming households is positively influenced by the yield and vocational training. In addition, income from rice production (RICINC), and off-farm income (OFFINC) exerted a positive and statistically significant effect on the households' welfare in the pooled data and among the sub-population of the upland and lowland rice farming households. The years of formal education (YEDUC) and years of residence in the village, were positive and statistically significant in generating welfare improvement in the pooled data and among the lowland rice farming households.

Household size negatively affects welfare in the pooled data and among the subpopulations of the upland and lowland rice farmers. In the pooled data, the coefficient of age has a negative and statistically significant effect on welfare. This implies that as age of the household increases, welfare also increases. However, as revealed by the positive and statistically significant coefficient of age2, age will increase to a certain level and then welfare will start to decrease.

\section{Summary, conclusion and policy recommendations}

The study assessed factors that determined the intensity of IRVs adoption and the determinants of market participation and their effect on welfare of rural households. It can be stated that higher adoption of IRVs would lead to an increase in rice yield and rural farmers could, consequently, have marketable surplus. It this is marketed it would lead to an increase in household income and by extension generate improvement in household's welfare.

The farmers are still in the productive age at 45 years. The majority of the rice farmers also participate and obtain addition income from off-farm activities. Contact with extension agents and membership of farmers' organisation is still very low. The farm size is small and fragmented. Access to credit is major constraint in rice production and farmers need to travel an average of $4.39 \mathrm{~km}$ to the nearest seed sources. The IRVs have higher yield compared to the traditional rice varieties. Adopters of IRVs are better off in terms of welfare than the non-adopters. In addition, farmers that participate in the market are wealthier than those who did not participate in the market. 
Variation exists in the factors that significantly determine the intensity of IRV adoption in the entire collection/range of data - data of the upland, lowland and irrigated rice producing systems. The results of the multivariate analyses adopted to examine the effect of market participation on welfare using the Heckman two-step model also show significant variation in the effects of the included variables by rice producing systems. Gender of the household head (GNR), Yield, years of formal education, (YEDUC), access to seed (SEACES) and cost of seed in $\mathrm{kg}$ are the variables that increase the probability that a farmer will participate in the rice producers' market. The probability that the farmer in the upland rice system will participate in the rice output market is significantly increased by the gender of the household head (GNR), yield and ownership of the/a house (HOWN), while the probability of participating in the market among the farmers in the lowland rice producing system is significantly increased by gender of household head (GNR), years of formal education (YEDUC), yield and ease of access to seed (SEACES). Welfare of the farming households is influenced by yield, income and education of the household head.

It is necessary to increase the intensity of IRVs adoption to generate an increase in yield. Excess output above the consumption level of the households will generate marketable surplus, which encourages farmers to participate in the output market. The findings show that market participation increases households' welfare. Therefore, increase in those variables that lead to increasing IRVs adoption and market participation should be the focus of any welfare enhancing programs or policy. Specifically, we recommend the formation of farmers' associations should be encouraged. Access to seed and information about the improved rice varieties are also essential in order to increase the intensity of its adoption. Programmes that would improve contact with extension agents, access to credit, educational background and enlarging the area devoted to the cultivation of improved rice varieties should be promoted in order to increase market participation and generate improvement in the welfare of rural households.

\section{Endnotes}

${ }^{1}$ See the description and definition of the variables in Table 1.

${ }^{2}$ See the description and definition of the variables used in the model in Table 1.

Competing interests

The authors declare that they have no any competing interests.

Authors' contributions

BAA: Paricipated in the data collection, analysis and result interpretation. AK: participated in the paper writing, analysis and organization of the Tables. AD: coordinated the data collection, data entry and supervised the report wrting. All authors read and approved the final manuscript.

\section{Acknowledgements}

This study benefited tremendously from the financial support of USAID and the scientific support of the Africa Rice Center, Cotonou, Benin Republic. We also gratefully appreciate the supports of all the collaborating institutes (NCRI, CRS, NBS, and Department of Agricultural Economics, University of Ibadan, Nigeria). To all the farmers and the enumerators in all the study areas we say a very big thank you.

Author details

${ }^{1}$ Agricultural Economics, University of Ibadan, Ibadan, Ibadan 200001, Nigeria. ${ }^{2}$ Socio-Economic Program, International Maize and Wheat Improvement Centre (CIMMYT), Ankara 06170, Turkey. ${ }^{3}$ Economic Sciences and Management, Gaston Berger University, Saint-Louis, Senegal. 
References

Abay, A. (2007). Vegetable Market Chain Analysis: The Case of FogeraWoreda in ANRS of Ethiopia. An Msc.Thesis Presented to the School of Graduate Studies of Haramaya University

Abayneh Y, Tefera T (2013) Factors influencing market participation decision and extent of participation of haricot bean farmers in Meskan District, Ethiopia. Int J Manag Dev Stud 2(8):17-25

Adeoti Al (2009) Factors Influencing Irrigation Technology Adoption and Its Impact on Household Poverty in Ghana. Journal of Agriculture and Rural Development Tropics and Subtropics 109:51-63

Adesina AA (1996) Factors a ecting the adoption of fertilizers by rice farmers in Cote d'Ivoire. NutrientCycling in Agroecosystems 46:29-39

Adesina AA, Seidi S (1995) Farmers' perceptions and adoption of new agricultural technology: analysis of modern mangrove rice varieties in Guinea-Bissau. Quarterly. Journal of international Agriculture 34(4):358-71

Adugna, G. (2009). Analysis of Fruit and Vegetable Market Chains in Alamata, Southern zone of Tigray: The Case of Onion,Tomata and Papaya. An Msc. Thesis Presented to the School of Graduate Studies of Alemaya University

Alavalapati JRR, Luckert MK, Gill DS (1995) Adoption of agroforestry practices: A case study from Andhra Pradesh, India. Agrofor Syst 32(1):1-14

Alene AD, Poonyth D, Hassan RM (2000) Determinants of adoption and intensity of use of improved maize varieties in the central highlands of Ethiopia: a Tobit analysis. Agrekon 39(4):633-643

Alene AD, Manyong VM, Omanya G, Mignouna HD, Bokanga M, Odhiambo G (2007) Smallholder market participation under transactions costs: Maize supply and fertilizer demand in Kenya. Food Policy 33(4):318-328

Alene AD, Manyong VM, Omaya G, Mignouna HD, Bokanga M, Odhiambo G (2008) Smallholder market participation under transaction costs: maize supply and fertilizer demand in Kenya. Food Policy 33:318-328

Amare M, Asfaw S, Shiferaw B (2012) Welfare impacts of maize-pigeonpea intensification in Tanzania. Agric Econ 43(1):1-17

Astewel T (2010) Analysis of rice profitability and market chain: the case of forega woreda, South Gondar zone, Amhara national regional State, Ethiopia. An M.Sc. thesis presented to school of graduate studies of Haramaya University.

Awotide BA, Awoyemi TT, Diagne A, Ojehomon VT (2011) Impact of access to subsidised certified improved rice seed on income: Evidence from Rice Farming Households in Nigeria. OIDA Int I Sustain Dev 02:12

Awotide BA, Diagne A, Wiredu AN, Vivian Ebihomon O (2012) Wealth status and agricultural technology adoption among smallholder rice farmers in Nigeria. OIDA Int J Sustain Dev 05(2):97-114

Awotide B, Karimov A, Diagne A, Nakelse T (2013) The impact of seed vouchers on poverty reduction among smallholder rice farmers in Nigeria. Agric Econ 44(2013):647-658

Awotide BA, Abdoulaye T, Alene A, Manyong VM (2014) Assessing the extent and determinant of adoption of improved cassava varieties in south-western Nigeria. J Dev Agric Econ 6(9):376-385

Bamire AS, Fabiyi YL, Manyong VM (2002) Adoption pattern of fertilizer technology among farmers in the ecological zones of South- western Nigeria: A Tobit analysis. Aust J Agr Res 53:901-910, http://dx.doi.org/10.1071/AR01095

Becerril J, Abdulai A (2010) The impact of improved maize varieties on poverty in Mexico: A propensity Score Matching approach. World Dev 38(7):1024-1035

Chebil A, Nasr H, Zaibet L (2009) Factors affecting Farmers' willingness to adopt salt-tolerant forage crops in SouthEastern Tunisia. Afr J Agric Resour Econ 3(1):19-27

Chikuvire TJ, Moyo M, Murewa M, Mutenje MJ, Nkyakudya IW (2006) Hidden overburden of female headed households in guar bean production: Zimbabwe experience. J Int Women's Stud 8:1

Cunningham LT, Brown BW, Anderson KB, Tostao E (2008) Gender differences in marketing styles. Agric Econ 38(1):1-7

Dercon S, Christiaensen L (2007) Consumption risk, technology adoption, and poverty traps: Evidence from Ethiopia", Policy Research Working Paper No. 4257. World Bank, Washington, DC

Dereje H (2006) Assessment of farmers' evaluation criteria and adoption of improved bread wheat varieties in Akaki, central Ethiopia. M.Sc. Thesis (Unpublished) Presented To School of Graduate Studies of Alemaya University

Diagne A, Demont M (2007) Taking a new look at empiricalmodels of adoption: average treatment effect estimation of adoption rates and their determinants. Agric Econ 37(2-3):201-210

Diagne A, Adekambi SA, Simtowe FP, Biaou G (2009) The Impact Of Agricultural Technology Adoption On Poverty: The Case of Nerica Rice Varieties in Benin. A shorter version of the paper is being presented as contributed paper at the 27th Conference of the International Association of Agricultural Economists. August 16-22, 2009. Beijing, China

Dontsop-Nguezet PM, Diagne A, Okoruwa VO, Ojehomon VET (2011) Impact of improved rice technology adoption (NERICA varieties) on income and poverty among rice farming households in Nigeria: a local average treatment effect (LATE) approach. Quarterly Journal of International Agriculture 50(3):267-291

Dontsop-Nguezet PM, Diagne A, Okoruwa VO, Ojehomon VET (2012) Estimation of Actual and Potential Adoption Rates and Determinants of NERICA Rice Varieties in Nigeria. International Association of Agricultural Economists 2012 Conference, Foz do Iguaçu, Brazi

Dorward A, Fan S, Kydd J, Lofgren H, Morrison J, Poulton C, Rao N, Smith L, Tchale H, Thorat S, Urey I, Wobst P (2004) Institutions and Policies for Pro-poor Agricultural Growth. Development Policy Review 22(6):611-622

Ellis F (2005) Rural livelihoods and diversity in developing countries. Oxford University Press, Oxford

Enete AA, Igbokwe EM (2009) Cassava Market Participation Decision of Producing Households in Africa. Tropicultura 27:129-136

Eswaran M, Kotwal A (1990) Implications of credit constraints for risk behaviour in less Developed economies". Oxford Econ Papers 42(2):473-482

Greene WH (2003) Econometric Analysis. Pearson, New York, p 1026

Hassan R, Kiairie N, Mugo N, Robin O, Laboso A (1998) Adoption patterns and performance of improved maize in Kenya. In: Rashid H (ed) Maize technology development and transfer: a GIS application for research planning in Kenya. CAB International, Wallingford

Heckman JJ (1976) The common structure of statistical models of truncation, sample selection and limited dependent variables and a sample estimator for such models. Ann Econ Soc Meas 5:475-492

Heckman JJ (1979) Sample selection bias as a specification error. Econometrica 47:153-161

Heckman JJ (1980) Sample selection bias as a specification error. In: female labour supply: theory and estimations, ed.J. P.Smith. Princeton University Press, Princeton, pp 206-249 
Hoffman R, Kassouf AL (2005) Deriving conditional and unconditional marginal effects in log earnings equations estimated by Heckman's procedure. Appl Econ 37:1303-1311

Itana, A. 1985. An Analysis of Factors Affecting the Adoption and Diffusion Patterns of Packages of Agricultural Technologies in Subsistence Agriculture: A Case Study in two Extension Districts of Ethiopia". Unpublished,M.Sc. thesis. Alemaya University, Alemaya

Jagwe JN (2011) Impact of transaction costs on the participation of smallholder farmers and intermediaries in the banana markets of Burundi, Democratic Republic of Congo and Rwanda. A PhD Thesis (Agricultural Economics) submitted to the University Of Pretoria, South Africa.

Jaleta M, Gebremedhin B, Hoekstra D (2009) Smallholder commercialisation: processes, determinants and impact, Discussion paper No. 18: improving productivity and market success of Ethiopian farmers, improving market opportunities. International Livestock Research Institute, Nairobi

Jayne TS, Mather D, Mghenyi E (2005) Smallholder farming in difficult circumstances: Policy issues for Africa, MSU International Development Working Paper No. 86, 2006. Department of Agricultural Economics and the Department of Economics, Michigan State University, East Lansing

Johannes CB, Li TK, Zhou X, Johnston JA, Dworkin RH (2010) The prevalence of chronic pain in United States adults: Results of an internet-based survey. J Pain 11:1230-1239

Kaguongo W, Ortmann GF, Wale E, Darroch MAG, Low J (2010) Factors influencing adoption and intensity of adoption of orange flesh sweet potato varieties: evidence from extension intervention in Nyanza and western province, Kenya, Poster presented at the Joint 3rd African Association of Agricultural Economics Conference, Cape Town, South Africa, September, 19-23

Kassie M, Shiferaw B, Muricho G (2011) Agricultural technology, crop income, and poverty alleviation in Uganda. World Dev 39(10):1784-1795

Maertens A, Barrett CB (2013) Measuring Social Networks' Effect on Agricultural Technology Adoption. Am J Agric Econ 95(2):353-359

Makhura, M., Kirsten, J., and Delgado, C. (2001). Transaction costs and smallholder participation in the maize market in the Northern Province of South Africa. Proceedings of the Seventh Eastern and Southern Africa Regional Conference, 11-15 February, Pretoria.

Martey E, Al-Hassan RM, Kuwornu KM (2012) Commercialization of smallholder agriculture in Ghana: A Tobit regression analysis. Afr J Agr Res 7(14):2131-2141

Matungul PM, Lyle MC, Ortman GF (2001) Transaction costs and crop marketing in the communal areas of Impendle and Swayimana. KwaZulu Natal. Dev Southern Afr 18(3):347-363

Mendola M (2007) Agricultural technology adoption and poverty reduction: a propensity-score matching analysis for rural Bangladesh. Food Policy 32(2007):372-393

Musay AB, Bonsu OY, Seini W (2014) Market participation of smallholder maize farmers in the upper west regions of Ghana. Afr J Agric Res 9(31):2427-2435

Ojiako IA, Manyong VM, Ikpi AE (2007) Determinants of rural framers' improved soybean adoption decision in Northern Nigeria. J FoodAgric Environ 5(2):215-223

Olwande J, Mathenge M (2012). Market participation among poor rural households in Kenya. In paper presented at the international association of agricultural economists triennial conference, Brazil. (18-24 August).

Omiti J, Otieno D, Nyanamba T, Mc Cullough E (2009a) Factors influencing the intensity of market participation by smallholder farmers: A case study of rural and peri-urban areas of Kenya. Afjare 3(1):57-82

Onoja AO, Usoroh BB, Adieme DT, Deedam NJ (2012) Determinants of market participation in Nigerian small-scale fishery sector: evidence from Niger delta region Consilience. J Sustain Dev 9(1):69-84

Polson R.A and Spencer D.S.C (1992). The technology adoption process in subsistence agriculture: the case of cassava in South western Nigeria. IITA Research no.5, pp.12-16

Rahmeto Negash, 2007. Determinants of Adoption of Improved Haricot Bean Production Package in Alaba Special Woreda, Southern Ethiopia. A Thesis Submitted to the Department of Rural Development and Agricultural Extension, School of Graduate Studies at Haramaya University, Ethiopia.

Randela R.r Alemu G. and Groenewald (2008). Factors enhancing market participation by small-scale cotton farmers: Agrekon 47(4).

Roger EM (1983) Diffusion ands Innovation, 3rd edn. Free Press, New York

Rogers EM, Shoemaker FF (1971) Communication of innovations: A cross culture approach. The Free Press, Collier Macmillan Publishing Inc, NY, pp 11-28

Rosenzweig M, Binswanger H (1993) Wealth, weather risk, and composition and profitability of agricultural investments". Econ J 103(416):56-78

Sebatta C, Mugisha J, Katungi E, Kashaaru A, Kyomugisha H (2014) Smallholder farmers' decision and level of participation in the potato market in Uganda. Mod Econ 5:895-906

Shepherd A (2007) Approaches to linking producers to markets. Agricultural management, marketing and financial occasional paper 13. Food and Agricultural Organisation of the United Nations, Rome, Rural Infrastructure and Agro-Industries Division

Shiyani RL, Kakadia BH, Tarpara VD (2002) Socio-economic impact of watershed development in South Saurashtra Region of Gujarat. Journal of Rural Development - Hyderabad. Pub Ind 21(3):411-431

Sigei KG, Bett KH, Kibet KL, Mutai CM (2013) Determinants of market participation among small-scale pineapple farmers in Kericho County, Kenya. J Econ Sustain Dev 4(19):59.66

Siziba S, Kefasi N, Diagne A, Fatunbi AO, Adekunle AA (2011) Determinants of cereal market participation by subSaharan Africa smallholder farmer. Learning publics J. Agric Environ Stud 2(1):180-193

Taha M (2007) Determinants of the adoption of improved onion production package in Dugda Bora district, East Shoa, Ethiopia. M.Sc. Thesis (Unpublished) Presented To School of Graduate Studies of Haramaya University

Tobin J (1958) Estimation of relationships for limited dependent variables. Econometrica (The Econometric Society) 26(1):24-36

Verteeg MN, Koudokpon V (1993) Participatory farmer testing of four low external input technologies to address soil fertility decline in mono province (Benin). Agr Syst 42:265-276 
Vigneri M, Vargas HR (2011) Mainstreaming Gender Sensitivity in Cash Crop Markets Supply Chains. Working Paper No. 11-08, ESA, FAO. http://www.fao.org/docrep/013/am313e/am313e00.pdf.

Wang'ombe JG (2008) The Potato Value Chain in Kenya and Uganda. Maastricht School of Management, DBA Assignment

Wooldridge JM (2002) Econometric analysis of cross section and panel data, XXIII (p. 752). MIT press, Cambidge World Bank (2006).World Development Report 2007: Agriculture for Development, Washington D.C

World Bank (2007) World Development Report 2007: Agriculture for Development. Washington D.C.

Wu H, Ding S, Pandey S, Tao D (2010) Assessing the impact of agricultural technology adoption on farmers' well-being using propensity score matching analysis in Rural China. Asian Economic Journal 24(2):141-160

Yesuf M, Kassie M, Köhlin G. (2009) Risk implications of farm technology adoption in the Ethiopian Highlands. Environment for Development Discussion Paper. 09-13.

\section{Submit your manuscript to a SpringerOpen ${ }^{\circ}$ journal and benefit from:}

- Convenient online submission

- Rigorous peer review

- Immediate publication on acceptance

- Open access: articles freely available online

- High visibility within the field

- Retaining the copyright to your article

Submit your next manuscript at $>$ springeropen.com 